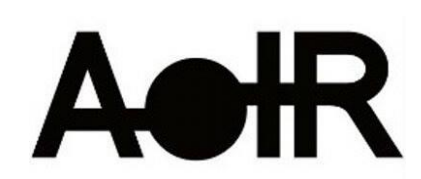

Selected Papers of \#AolR2019: The $20^{\text {th }}$ Annual Conference of the Association of Internet Researchers Brisbane, Australia / 2-5 October 2019

\title{
"OPEN DATA MEANS BUSINESS": WHEN MONETARY POTENTIAL IN OPEN DATA USURPS ASPIRATIONS FOR ACCOUNTABILITY AND TRANSPERANCY IN THE SMART CITY
}

\author{
Güneş Tavmen \\ King's College London
}

Following the common criticism that smart cities are top-to-bottom, neoliberal, and technocratic corporate-led ambitions (McNeill, 2015; Söderström et al., 2014; Hollands, 2015; Wiig, 2015), open data has become pivotal in transforming smart city discourses into 'citizen-centric ones (also see Kitchin, 2014 and Barns, 2016) despite a lack of understanding its limitations, and political and contingent nature (Worthy, 2015). For example, in 2013, in the first smart city plan prepared by the Greater London Authority (GLA), open data was considered crucial in order to foster citizen engagement (see Coleman, 2013); hence it is described as a "unique approach" in which "the citizen comes first" (Foth et al. 2016). That was due to the assumption that when everyone can freely access, share and use data instead of being locked in silos, it would automatically change top-to-bottom smart cities. Partly due to being critically under-theorised (Kitchin, 2014a), the concept of open data is often conflated with 'open government', hence laden with the same kind of expectations such as increased citizen participation and government transparency (Yu \& Robinson, 2012).

Prior to being incorporated into smart city discourses, open data had become a matter of governmental strategy for many European countries and the USA since the late 2000s (Huijboorn and van den Broek, 2011). The UK has been one of the pioneers and indeed drivers of open data initiatives on both domestic and international scale as reflected on its position at the summit of the global open data rankings for consecutive years (e.g. Open Data Barometer), regardless of the specific ideological complexion of successive UK governments. According to Ruppert (2015), OGD became an essential performance indicator together with the "Transparency Agenda": in 2011, the coalition government promised a "transparency revolution" that would enable an effective open data ecosystem, and would yield, in David Cameron's terms, "a whole army of effective armchair auditors" (Worthy, 2015: 789). However, a big shift in the discourse occurred during the Conservative - Liberal Democrat coalition government during the aftermath of

Suggested Citation (APA): Tavmen, G. (2019, October 2-5). "Open Data Means Business": When Monetary Potential in Open Data Usurps Aspirations for Accountability and Transperancy In the Smart City. Paper presented at AolR 2019: The $20^{\text {th }}$ Annual Conference of the Association of Internet Researchers. Brisbane, Australia: AolR. Retrieved from http://spir.aoir.org. 
the financial crisis as a result of which open data has been "economised" (Brown, 2015). Accordingly, it was in 2012, when Tim Berners-Lee and Nigel Shadbolt received a generous funding to establish the Open Data Institute (ODI) to work on unlocking the business value of open data. Since then, the ODI has become an established authority on open data - not only in the UK but also internationally.

My intervention with this paper is to show how open data is mobilised as an apparatus (Foucault, 1980) that is a benign economic tool within governance. In order to address open data as a governmental apparatus, I look into discursive and non-discursive formations that are often embedded in a system of dispersion, yet within an order of relationality and regularity (Foucault, 1977: 38). For Foucault (1977: 45), to understand the emergence of an apparatus, one should investigate the relation that exists between institutions, economic and social processes for what makes up a discourse is not a privileged object but dispersed objects. As such, the object of this paper is not open data per se, but the ways in which open data is located within smart city governmentality as a form of conduct. This is to say, this paper approaches open data as an apparatus within the implementation of an entrepreneurial and technocratic smart city agenda instead of being a tool to enhance transparency and accountability for London. To this end, after a brief overview of how open data (movement) emerged in a historical context, I will then continue to show to what ends it has been adopted and endorsed by the UK public bodies from 2009 and onwards, and show how the transformation in open data discourse from transparency and accountability to "raw material for innovation" took place. Through this historical lineage, I will be able to provide a background to the circumstances under which the ODI was established and has become a nondiscursive practice itself by developing, reiterating and materialising the dominant open data discourse in the context of smart city. My findings on the ODI are the result of a close study of the organisation. To do that, I attended their public events that I identified as relevant to smart cities between late-2014 to mid-2017, interviewed an employee, and audited a number of policy documents pertaining to them. Consequently, I argue that there has been a significant lack of institutionalised effort in delivering civic opportunities to progressive ends as a result of the overwhelming monetary potential emphasis despite once open data was advocated to enhance democracy. In doing so, I will foreground the political nature of open data despite the open data advocates' claim that open data movement is above ideologies and politics (Bates, 2012, 2013), therefore has been an "overly polite" one that chose to collaborate closely with consecutive governments instead of contesting them (Steinberg, 2016).

\section{References}

Barns S (2016) Mine your data: open data, digital strategies and entrepreneurial governance by code. Urban Geography, 37(4): 554-571

Bates J (2012) "This is what modern deregulation looks like": Co-optation and contestation in the shaping of the UK's Open Government Data Initiative. The Journal of Community Informatics 8(2). 
Bates J (2013) The Domestication of Open Government Data Advocacy in the United Kingdom: A Neo-Gramscian Analysis. Policy and Internet 5(1): 118-136.

Brown W (2015) Undoing the Demos: Neoliberalism's Stealth Revolution. Masachusettes: The MIT Press.

Foth M, Hudson-Smith A and Gifford D (2016) Smart cities, social capital, and citizens at play: A critique and a way forward. In: F. X. Olleros \& M. Zhegu, eds. Research Handbook on Digital Transformations. Cheltenham: Edward Elgar Publishing, pp. 203-221.

Foucault M (1977) The Archaeology of Knowledge. London: Tavistock Publications.

Foucault M (1980) The Confession of the Flesh. In: Gordon C (ed)

Power/Knowledge. Prentice Hall, pp.194 - 228.

Kitchin R (2014) Opening up smart cities: A report on the Smart City Expo World Congress. In: the Programmable City. Available at:

http://www.maynoothuniversity.ie/progcity/2014/11/opening-up-smart-cities-a-reporton-the-smart-city-expo-world-congress/ (Accessed 30 November 2014).

McNeill D (2015) Global firms and smart technologies: IBM and the reduction of cities. Transactions of the Institute of British Geographers.

Ruppert E (2015) Doing the Transparent State: open government data as performance indicators. In: Rottenburg R, Merry SE, Park S-J and Mugler J (eds) $A$ World of Indicators: The making of governmental knowledge through quantification. Cambridge: Cambridge University Press: pp. 127-150.

Soderstrom O, Paasche T and Klauser F (2014) Smart Cities as corporate storytelling. City, 18(3): 307-320.

Steinberg T (2016) Over-Politeness Is the Fatal Flaw in the Open Data Movement. Available at: https://civichall.org/civicist/over-politeness-is-the-fatal-flaw-in-the-opendata-movement/ (Accessed 28 April 2016).

Wiig A (2015) IBM's smart city as techno utopian policy mobility. City: 258-273.

Worthy B (2015) The Impact of Open Data in the UK: Complex, Unpredictable, and Political. Public Administration 93(3): 788-805.

Yu H and Robinson D (2012) The new ambiguity of 'open government'. (February 28, 2012). UCLA Law Review Discourse 52(11): 178-208. 